\title{
Mentoring Characteristics and Functions Important to Men and Women within Intercollegiate Athletic Administration
}

\author{
Glenna Bower ${ }^{1}$, Mary Hums², and Sarah Williams ${ }^{2}$ \\ ${ }^{1}$ University of Southern Indiana and ${ }^{2}$ University of Louisville
}

\begin{abstract}
Female athletic administrators were asked about the role of mentoring in their careers as women while male athletic administrators were asked about the role of mentoring in their careers as men working in intercollegiate athletic administration. The researchers gathered and compared information on mentor characteristics as well as career and psychosocial benefits of having a mentor. Participants were 518 female and 778 male athletic administrators working at NCAA Division I, II, and IIII, NAIA, NCCAA, and NJCAA schools. A three-step content-analytic procedure was used to analyze the qualitative data. Men identified being trustworthy, supportive, respected, and a good listener while women identified being supportive, hardworking, and knowledgeable as the most important mentor characteristics. Men most frequently named coaching and challenging assignments as career benefits from mentors while women named exposure/visability and coaching. Both men and women most frequently identified counseling and role modeling as psychosocial benefits from mentors.
\end{abstract}

Keywords: athletic administration; gender differences; mentoring; career development

\section{Introduction}

Mentoring relationships can serve as critical career resources for employees in any organization. Mentoring is "a process in which a more experienced person (i.e., the mentor) serves as a role model, provides guidance and support to a developing novice (i.e., the protégé), and sponsors that individual's career progress" (Weaver \& Chelladurai, 1999, p. 25). This definition was developed by scholars in the academic discipline of Sport Management and subsequently utilized by other Sport Management researchers as well (Bower, 2011; Bower \& Hums, 2014). In addition to defining mentoring, researchers have defined a mentor as "an individual who has taken a personal interest in an individual and has guided, sponsored, or otherwise had a positive influence on their professional career development" (Allen, Poteet, \& Burroughs, 1997, p. 2). Mentors facilitate protégés' career advancement while contributing to protégés' personal growth and professional development (Kram, 1985). This 
definition, also utilized by Bower (2011) with coaches and Bower and Hums (2014) with female intercollegiate athletic administrators, sets the stage for this study.

Research consistently demonstrates how mentoring relationships provide substantial benefits associated with an array of positive career outcomes. Mentoring researchers in the sport industry have reported results with regard to increased job satisfaction, learning from experienced professionals, help with acquiring new skills and information, personal growth, and career mobility (Bower, 2011; Bower \& Hums, 2014; Dougherty, Dreher, Arunachalam, \& Wilbanks, 2013; Hancock, Grappendorf, Wells, \& Burton, 2017; Ransdell, Nguyen, Hums, Clark \& Williams, 2017; Taylor \& Wells, 2017).

While these basic benefits are well documented, one question that needs further investigation, particularly given the male-dominated nature of the sport industry, is do men and women experience mentoring relationships differently. Gender differences have been shown to impact networking behavior and career enhancement (Forret \& Dougherty, 2004). Men have more experience mentoring men than mentoring women and, therefore, male protégés progress further and benefit more from mentoring relationships than their female counterparts (Bickel, 2014). Men and women have been shown to differ in experiences with and expectations of mentors. Mentoring relationships for male protégés are typically more formal and often more closely related to career outcomes than mentoring relationships for female protégés (Ragins \& Cotton, 1999). Additionally, female protégés with male mentors have been shown to earn significantly more than female protégés with female mentors (Ragins \& Cotton, 1999).

In intercollegiate athletics, proteges with same-sex mentors have been found to receive significantly more psychosocial and career mentoring than protégés with opposite-sex mentors (Avery, Tonidandel, \& Phillips, 2008). The masculine power perspective in sport even influences women's intercollegiate athletics (Avery et al., 2008), an area once traditionally populated by women in leadership positions. This shift further supports the need for examining mentoring relationships in intercollegiate athletics for both men and women. It is important to examine potential gender differences in mentoring experiences in sport to better understand gendered opportunities and perceptions of exclusively male social networks in intercollegiate athletics (Walker \& Bopp, 2011).

The number of female intercollegiate athletic administrators remains low, however, (Acosta \& Carpenter, 2014) resulting in a scarcity of female mentors for future generations of leaders. This is particularly troubling, as in intercollegiate athletics, protégés with same-sex mentors have been found to receive significantly more psychosocial and career mentoring than protégés with opposite-sex mentors (Avery et al., 2008). Male leaders and managers reported having more experience mentoring fellow males than mentoring women. Those male protégés therefore have access to support and mentorship that allows them to progress further and benefit more from mentoring relationships than their female counterparts (Bickel, 2014). The byproduct of such mentoring relationships is that women are not provided assistance with the career functions necessary to lead them to intercollegiate athletic administrative 
positions (Bower, 2011; Bower \& Hums, 2014; Dougherty et al., 2013). Further exploration into the mentoring functions of both men and women in intercollegiate athletics is necessary to support the advancement of women into sport leadership positions. A better understanding of the comparisons and differences by gender will provide further guidance for promoting equity in the workplace.

The present article focuses on the role of mentoring for people working in a particular line of business - the sport industry. In the sport industry, mentoring benefits have been shown to include increased job satisfaction as well as personal growth and career mobility for women working in intercollegiate coaching (Bower, 2011; Inglis, Danylchuk, \& Pastore, 2000) and women working in intercollegiate athletic administration (Bower 2011; Bower \& Hums, 2014; Smith, Taylor, \& Hardin, 2016). While researchers have focused on the impact of mentoring on the careers of women working in the sport industry, no studies have specifically examined men and their experiences with the mentoring relationship in the sport industry. In intercollegiate athletics, protégés with same-sex mentors have been found to receive significantly more psychosocial and career mentoring than protégés with opposite-sex mentors (Avery, Tonidandel, \& Phillips, 2008).

In the present study, the researchers queried both men and women about the impact of mentoring on their careers. The female participants were specifically asked about the role of mentoring in their careers as women working in intercollegiate athletic administration while the male participants were specifically asked about the role of mentoring in their careers as men working in intercollegiate athletic administration.

\section{Theoretical Background}

According to mentor role theory, the gender of the mentor and protégé may relate to the mentoring functions provided to the protégé (Kram, 1985). Kram (1985) identified two distinct, but related, functions provided by mentors: career and psychosocial. The career development functions (sponsorship, exposure and visibility, coaching, protection, and challenging assignments) facilitate the protégé's ability to advance in the organization. Psychosocial functions (role modeling, acceptance and confirmation, counseling, and friendship) contribute to the protégé's personal growth and professional development (Kram, 1985). Existing mentorship theory from Ragins' work on gender and mentoring (Ragins, 1997, 2002) and social exchange theory (Olian, Carroll, \& Giannantionio, 1993) posit that the gender composition of the mentoring relationship is a critical factor affecting mentoring functions and outcomes. This holds true in the sport industry where researchers have found the same type of results in coaching and intercollegiate athletic administration (Bower, 2011; Bower \& Hums, 2014; Dougherty et al., 2013; Hancock et al., 2017; Taylor \& Wells, 2017).

According to Ragins' $(1997,2002)$ theory of mentoring, gender makes a difference in mentoring relationships because the mentor may be someone who possesses a high degree of power within an organization. In addition, Ragins asserted that the experiences one has as a mentor may impact the development and effectiveness of the mentoring relationship. For example, a female protégé may be perceived as 
weaker than her male counterparts and thus be accorded a greater degree of protection by mentors. Ragins proposed that because the majority of male mentors have more power in organizations than female mentors, they should be better able to provide career development functions and encourage positive organizational outcomes.

Looking at the sport industry, mentoring relationships are critical for the career success of women wanting to advance to leadership positions in campus recreation (Bower, Hums, \& Keedy, 2006), sport and physical activity academic disciplines (Bower, 2006), intercollegiate athletics (Lough, 2001; Weaver \& Chelladurai, 2002), and interscholastic athletics (Bloom, Durand-Bush, Schinke, \& Salmella, 1998). Several theoretical perspectives suggest that men may be more apt to provide career mentoring whereas women may be more apt to provide psychosocial mentoring. More specifically, literature suggests that women are more likely than men to provide psychosocial support such as emotional support and informal counseling (Allen, Russell, \& Maetzke, 1997; Burke, McKeen, \& McKenna, 1993; Chester \& Mondello, 2012).

According to social role theory (Bem, 1974), the feminine gender role encourages women to be caring and nurturing. On the other hand, the instrumental focus of career-related mentoring is associated more with men and perceptions that men hold greater power within organizations (Ragins \& Sundstrom, 1989). This theory held true for the sport industry in regard to women working in coaching and intercollegiate athletics who reported female mentors displayed more psychosocial functions in comparison to career functions (Bower, 2011; Bower \& Hums, 2014). Since this is the first study exploring men's experiences in mentoring, as of this writing no comparative data exists to support this theory in the sport industry. This gap in the literature provides a significant reason to conduct this study and add to the body of literature focused on how mentoring relationships can potentially enhance the career development and psychosocial development of both mentors and protégés.

Through the career functions of sponsorship, coaching, protection, exposure-and- visibility, and challenging assignments, a protégé may learn the ropes of organizational life and become better prepared for advancement opportunities. For example, the career-development sponsorship function allows a mentor to build the reputation of a protégé wanting to pursue a career in intercollegiate athletic administration. A mentor may promote a man or woman by highlighting his/her potential at an athletic board meeting. By providing exposure and visibility, the mentor introduces the protégé to important people in the field, such as athletic directors at other conference schools. Expanding the protégé's network creates opportunities to develop relationships that allow for greater future advancement opportunities. A mentor also provides knowledge and skills as well as productive feedback via the career development coaching function. A protégé may have the opportunity to observe an athletic director in his or her role working with donors. A mentor can also exhibit the protection function, shielding the protégé from taking on excessive committee work or responsibilities outside of athletics. Finally, the mentor may assign the protégé challenging assignments such as overseeing the budget of a revenue-producing sport 
in order to prepare him or her to undertake greater intercollegiate athletic administrator responsibilities (Kram, 1985).

The psychosocial functions identified by Kram (1985) include role modeling, acceptance and confirmation, counseling, and friendship. Role modeling provides the protégé with guidance on performing organizational tasks while observing the behaviors, attitudes, and values of the mentor (Bandura, 1977; Hackett \& Betz, 1981; Itoh, 2014). An inexperienced athletic administrator may be able to sit in on high level athletic department meetings and observe an experienced athletic administrator. In acceptance and confirmation, the protégé may be provided with confidence, mutual trust, encouragement, support, and positive feedback from a mentor in intercollegiate athletic administration. Counseling allows the mentor to help the protégé solve personal conflicts that might distract from effective job performance. Differences and conflicts often arise between athletic department personnel so having a trusted mentor to talk with about political situations or difficult decisions is essential for protégé development. Finally, friendship is a social interaction which allows the protégé to share personal experiences while being removed from the pressures within the intercollegiate athletic department. People work long hours in athletics and being collegial can benefit the environment and the people working there.

Kram (1985) also identified how the mentoring relationship constitutes a reciprocal, interactive process of give and take between the mentor and the protégé in helping each other reach their goals. This reciprocal interactive process may best be explained by social exchange theory. Social exchange theory:

Views the interaction between two people as an exchange where the cost of participation in the relationship is compared to the perceived benefits. The basic premise of social exchange theory indicates that if an individual perceives greater rewards than cost, he or she will be more inclined to develop the relationship (Olian et al., 1993, p. 2).

The social exchange in a mentor-protégé relationship may include material benefits along with psychological benefits of approval, respect, affection and esteem. For example, a protégé may select a mentor based on certain desirable attributes and/ or competencies with the anticipation of receiving career and psychosocial benefits useful in becoming a successful intercollegiate athletic administrator. The mentor may choose a protégé based on performance. If the protégé is a high performer, the mentor may perceive the protégé and the organization will be successful and so it is worth the time and effort to work together.

Substantial benefits can be associated with mentoring and career mobility in the sport industry. An examination of the characteristics and functions that relate to the mentor's perception of effective mentoring should lead to a better and more complete understanding of what constitutes beneficial mentoring relationships for both the mentor and the protégé 


\section{Purpose of the Study}

While mentoring relationships can benefit any employee, when looking at the predominantly male make-up of intercollegiate athletic administration, one could ask whether men and women experience these benefits similarly or differently. Therefore, the purpose of this study was to examine the mentoring relationships of men and women working in intercollegiate athletic administration. More specifically, the study gathered and compared information from both male and female athletic administrators on mentor characteristics, career benefits, and psychosocial benefits that could guide them toward advancement in intercollegiate athletic administration. The study addressed the following research questions:

(1) What mentoring characteristics were most frequently identified as important to the success of male and female intercollegiate athletic administrators?

(2) What career functions of the mentor were most frequently identified as important to the success of male and female intercollegiate athletic administrators?

(3) What psychosocial functions of the mentor were most frequently identified as important to the success of male and female intercollegiate athletic administrators?

\section{Significance of the Study}

The study has the potential to bridge theory and practice and to contribute to the body of the mentoring literature in three ways. First, the research provides information on the importance of mentoring relationships in the career development of men and women working in intercollegiate athletic administration. This information provides strategies for mentoring all young employees working in intercollegiate athletic administration. This may mean an athletic director works with athletic department personnel in developing a formal mentoring program for new employees, including coaches and administrators. Second, the intercollegiate athletic environment is fastpaced with athletic administrators working long hours and interacting with coaches, athletes, sponsors, fans, and the media. The information from this study may assist new male and female employees in learning ways to navigate this environment, thus aiding their career maturation. Finally, the responses from the male participants will add to the body of literature since this is a group which has not yet specifically been queried about how mentoring impacted their careers as men working in intercollegiate athletic administration.

\section{Method}

Both quantitative and qualitative data collection and analysis were used to address the research questions. Data were gathered and analyzed on the mentor character- 
istics and the career and psychosocial benefits of having a mentor in intercollegiate athletic administration.

\section{Participants}

The participants of the study were 518 women and 778 men working in intercollegiate athletic administration at NCAA Division I, II, IIII, NAIA schools, NCCAA schools, and junior colleges. The National Directory of College Athletics provided the email addresses of the participants.

The demographic data indicated the majority of men in the study were (a) athletic directors (34.6\%), (b) worked at the Division I level (48.7\%), and (c) were an average age of 35- 44 (32.5\%). The majority of the women in the study were (a) associate athletic directors (37.9\%), (b) worked at the Division I level (45.9\%), and (c) were an average age of 45-54 (30.2\%). Table 1 provides additional demographic information.

Table 1

Demographics

\begin{tabular}{lrr}
\hline \multicolumn{1}{c}{ Demographics } & Men & Women \\
\hline Current Athletic Administration Position Title & & \\
Athletic Director & 34.6 & 17.6 \\
Associate Athletic Director & 34.5 & 37.9 \\
Assistant Athletic Director & 27.0 & 29.2 \\
Other & 3.9 & 15.2 \\
Level of Current Athletic Administration Position & & \\
Division I & 48.7 & 45.9 \\
Division II & 15.8 & 19.7 \\
Division III & 17.6 & 24.5 \\
NCCAA & 1.2 & .6 \\
NAIA & 5.8 & 3.8 \\
Junior College & 10.9 & 5.4 \\
Age & & \\
$<25$ years & .4 & .4 \\
$25-30$ & 7.4 & 8.1 \\
$31-34$ & 9.7 & 13.4 \\
$35-44$ & 32.5 & 29.8 \\
$45-54$ & 27.5 & 30.2 \\
55 or above & 22.5 & 18.2
\end{tabular}


Table 1 (cont.)

Race/Ethnicity

Native American

Asian or Pacific Islander

African American

Hispanic

White

Other

Highest Level of Education

High School Graduate

Some college (includes Associate)

College Graduate

Master's

Doctoral

JD

( Associate)

$\begin{array}{rr}.5 & .4 \\ .7 & .2 \\ 7.8 & 8.9 \\ 2.3 & .8 \\ 87.5 & 88.4 \\ 1.2 & 1.2\end{array}$

\section{.5}

.4

.8

8.4

0.0

.8

21.4

67.1

73.0

5.9

5.8

3.4

Other

Approximate Income

Less than $\$ 19,999$

$\$ 20,000-\$ 39,999$

$\$ 40,000-\$ 59,999$

$\$ 60,000$ - \$79,999

$\$ 80,000$ - \$99,999

$\$ 100,000$ - \$119,999

$\$ 120,000$ - \$139,999

\$140,000 - \$159,999

\$160,000 - \$179,999

\$180,000- \$199,999

$\$ 200,000$ or higher

In regard to the mentoring relationship, the participants were asked if their mentor was inside or outside the athletic department and whether their mentor was male or female. Of the male respondents, $30.9 \%$ reported that their mentors were in the athletic department and $84.4 \%$ of those mentors were male. In addition, $62.9 \%$ of the men reported that their mentors were outside the athletic department and $86.3 \%$ of 
those mentors were males as well. Of the female respondents, $28.7 \%$ reported that their mentors were inside the athletic department and $62.3 \%$ of those mentors were male. In addition, $64.3 \%$ of the women reported that their mentors were outside the athletic department and $64.5 \%$ of those mentors were female as well.

\section{Procedures}

The researchers sent the Female Sport Manager Career Survey [FSMCS] (Bower $\&$ Hums, 2013) to 6134 participants $($ men $=4318$ and women $=1834)$ via Survey Monkey. After three weeks, a follow-up email was sent to all non-respondents. A total of 1296 surveys were returned for a return rate of $21.1 \%$ (518 women and 778 men). The return rate was relatively low as it is very difficult to determine the best time to conduct a survey with intercollegiate athletic administrators given the continuous amount of work year-round. However, one way to determine if respondents are representative of the population is to compare characteristics of the sample to demographics in the literature (Olson, 2006). The male respondents in this study were similar to previous studies in regard to age, ethnicity, and education. For example, the current study supported previous research by Whisnant, Pedersen, and Obenour (2002) who reported the average age of men being appointed as athletic directors was 47 (Division I), 42 (Division II), and 41 (Division III). Lapchick's (2018) Racial and Gender Report Card indicated that 86.1\% (Division I), 87.4\%\% (Division II), and $94.0 \%$ (Division III) were white. The men in the study were well-educated which supports previous research (Lumpkin, Achen, \& Hyland, 2015). Lumpkin et al. (2015) reported 61.7\% (Division I), 70.1\% (Division II), and 66.8\% (Division III) of the men in their study held a master's degree.

Similarities with the women were also noted with regard to age, ethnicity, education, and income. In the present study, $30.7 \%$ of the women were between the ages of $45-54$. In addition, $83.2 \%$ of the women were white. Both of these statistics are supported in previous research (Machida-Kosuga, Schaubroeck, \& Feltz, 2016; Schneider, Stier, Henry, \& Wilding, 2010).

Schneider et al. (2010) reported $86.4 \%$ of the Senior Woman Administrators were white while Machida-Kosuga et al. (2016) reported $90.24 \%$ of female athletic administrators were white. In addition, the women in the study were well-educated, with $73.2 \%$ holding master's degrees. The advanced degree information supports previous research on women working in intercollegiate athletic administration. Lumpkin et al. (2015) also reported that most female athletic directors (71.45) held master's degrees.

\section{Instrument}

The Female Sport Manager Career Survey was modified for male participants for the current study and will be referred to for purposes of this study as the Male Sport Manager Career Survey. This survey was chosen as it was utilized in a previous study on mentoring women working in intercollegiate athletic administration (Bower \& Hums, 2014). Appropriate modifications were made through the survey language to address career and mentoring information for men and their experience as 
males working in intercollegiate athletic administration. Although other surveys may have been applicable to the study, the researchers wanted to have an understanding of the participants' career paths, so they could understand where respondents were coming from in terms of their mentoring experiences. This was the first time using the survey to specifically focus on mentoring and to specifically focus on men. The survey questions were developed through extensive research of studies conducted on the career paths of women working in management of different sport segments, including intercollegiate athletics (Bower \& Hums, 2014; 2013), campus recreation (Bower \& Hums, 2003), professional basketball (Hums \& Sutton, 2000), sport for people with disabilities (Hums \& Moorman, 1999), and professional baseball (Hums $\&$ Sutton, 1999). A panel of experts examined the modified survey for content validity, biased items, and clarity before piloting. The panel of experts included one male athletic director, one male associate athletic director, and two females who conducted extensive research within the area of intercollegiate athletics.

The Male Sport Manager Career Survey elicited quantitative and qualitative responses in several areas including demographic information on age, race/ethnicity, highest level of education, income, and the mentoring relationship. Using open-ended questions, the men were asked to identify career path information, past and current work experiences, family and/or sport connections to intercollegiate athletics, the impact of playing sport on career choice, the most and least enjoyable aspects of their jobs as a man working in intercollegiate athletics, greatest challenges as a man working in intercollegiate athletics, and career advice for men entering the athletic administration job market. More importantly, the survey provided questions focused on identifying mentoring characteristics, and career and psychosocial functions important for career advancement in intercollegiate athletic administration, thus the focus of this study. Questions related to mentoring included "What mentoring characteristics were most frequently identified as important to the success of male athletic administrators?" "What career functions of the mentor were more frequently identified as important to the success of the male intercollegiate athletic administrator?" "What psychosocial functions of the mentor were more frequently identified as important to the success of the male intercollegiate athletic administered?".

\section{Data Analysis}

Demographic data frequencies were calculated using SPSS 19.0. A three-step content- analytic procedure was then used to analyze the qualitative data. The researchers organized and condensed the data by uploading the responses into Hyper Researcher 2.7. The investigators independently analyzed and coded the data. The researchers used constant comparative analysis to review the applicable comments from all three content areas (mentoring characteristics, career functions, psychosocial functions) and identified similarities and differences among the data, coding and sorting into appropriate categories (Rossman \& Rallis, 2011). Each content area of interest was reviewed, and similar comments were categorized into groups. The researchers used inductive reasoning by examining the categories that emerged from the data rather than placing comments into predefined categories. Once the comments were cate- 
gorized, themes were assigned names to capture the meaning of the groups of comments.

\section{Trustworthiness of the Study}

The trustworthiness of the study was strengthened by using multiple strategies of analysis introduced by Lincoln and Guba (1985). Credibility (internal validity) was strengthened by the use of constant comparative analysis (Neuman, 2010) to establish categories and develop themes from the open-ended questions. Constant comparative analysis strengthens the credibility of the study by creating authenticity of the data. The authenticity of the data is a "fair, honest, and balanced account of social life from the viewpoint of someone who lives it every day" (Neuman, 2010, p. 31).

The transferability (external validity) of the study was strengthened by examining and tallying comments to establish themes (Erlandson, Harris, Skipper, \& Allen, 1993). The dependability (reliability) of the study was strengthened by each researcher independently examining the data and debriefing to discuss the themes and categories. Finally, the confirmability (objectivity) of the study was strengthened by limiting bias of making any premature conclusions about the themes and/or categories, by reading and rereading the data, using constant comparative analysis, and research debriefing (Lincoln \& Guba, 1985).

\section{Results and Discussion}

The purpose of this study was to examine the mentoring relationship experiences of men and women working in intercollegiate athletic administration. More specifically, the study gathered and compared information from both male and female athletic administrators on mentor characteristics, career benefits, and psychosocial benefits that could guide them in advancing in intercollegiate athletic administration. The themes from the Research Questions are summarized in Table 2.

\section{Research Question \#1 - What mentoring characteristics were most frequently identified as important to the success of male and female athletic administrators?}

A total of $31.1 \%$ of the male participants indicated their mentor worked in the same athletic department. For those participants, $84.4 \%$ indicated their mentors were male and $15.6 \%$ indicated they were female. In addition, $63.5 \%$ of the men reported having a mentor outside the athletic department. Of the $63.5 \%$ of the participants identified as mentors outside the athletic department, $86.3 \%$ were male and $13.7 \%$ were female. The male intercollegiate athletic administrators identified several characteristics of their mentors that developed into the four themes of being (a) trustworthy, (b) supportive, (c) respected, and (d) a good listener.

The male intercollegiate athletic administrators most frequently identified their mentors as being trustworthy. For example, on respondent mentioned, "he [mentor] 
Table 2

Research questions and themes

Research Question \#1 - What mentoring characteristics were most frequently identified as important to the success of male and female athletic administrators?

Men

Theme 1. Being trustworthy

Theme 2. Being supportive

Theme 3. Being respected

\section{Women}

Theme 1. Being supportive

Theme 2. Being hardworking

Theme 3. Being knowledgeable

Theme 4. Being a good listener

Research Question \#2 - What career functions of the mentor were most frequently identified as important to the success of male and female intercollegiate athletic administrators?

Men

Theme 1. Coaching

Theme 2. Challenging assignments

Research questions and themes

\section{Women}

Theme 1. Exposure and visibility

Theme 2. Coaching

Research Question 3. What psychosocial functions of the mentor were most frequently identified as important to the success of male and female intercollegiate athletic administrators?

Men

Theme 1. Counseling

Theme 2. Role modeling

Theme 3. Acceptance and confirmation

\section{Women}

Theme 1. Counseling

Theme 2. Role modeling

Theme 3. Acceptance and confirmation 
was a very trustworthy person that I have looked up to my entire life." Another man mentioned, "my mentor was a trustworthy person that I have looked up to my entire career."

The second most frequently mentioned mentoring characteristics was being supportive, and one man explained,

My mentor and close friend has provided guidance and support throughout my intercollegiate athletic career, starting as an assistant coach. He has been invaluable in my professional growth. . . he [mentor] stuck by the employees who work hard and always supported his staff and coaches.

Another man wrote about his mentor being supportive,

She has provided me with amazing guidance and support. She ultimately is the reason why I got into Collegiate Athletics and have progressed as quickly as I have. She is still very supportive and is someone I can still rely on despite being at different universities.

The third most frequently mentioned mentoring characteristic was respect. One of the male intercollegiate athletic administrators said, "he [mentor] was very well respected throughout the business. Fair and reasonable... he is successful and respected as one of the best AD's in the country." Finally, the men reported their mentor was a good listener. For example, one male respondent explained, "my mentor was a godly man who listens well, offered advice when asked, has greater experience coaching and administration." Another man stated, "he was always there to listen and provide advice even when I do not want to hear it. Cares about me much more as a person."

A total of $28.7 \%$ of the female participants indicated their mentor worked in the same athletic department. The female participants identified $62.3 \%$ of their mentors as male and $37.7 \%$ as female. In addition, $64.3 \%$ of the women identified a mentor outside the athletic department. Of the $64.3 \%$ of the women who identified as mentors outside the athletic department, $35.5 \%$ were male and $64.5 \%$ were female. The female intercollegiate athletic administrators identified several characteristics of their mentors which developed into the three themes of being (a) supportive, (b) hardworking, and (c) knowledgeable.

The female intercollegiate athletic administrators most frequently described their mentors as being supportive. For example, one respondent mentioned, "he [mentor] is incredibly supportive and encouraging. He is always there to bounce off ideas; he never tries to 'solve' my issues, and he constantly makes me question what and why!" Another woman mentioned, "my work mentor knows me the best. She ALWAYS challenges me and is supportive of my desire to do something different."

The second most frequently mentioned mentoring characteristic was hard working. One woman explained, "I actually have three mentors, two females and one male. All three are incredibly helpful, intelligent, hard-working and excellent in every way and they guide/push/pull and inspire me daily." Another woman said, "my 
female mentor works on campus in administration. She is extremely hard worker and always does the right thing."

The third most frequently reported characteristic was knowledgeable. One of the female intercollegiate athletic administrators said, "[my mentor is a] strong individual who is knowledgeable and who also balances family with her career." Another woman stated, "I have the opportunity to work in a conference with very seasoned, knowledgeable AD's."

Comparison of Mentoring Characteristics. The mentoring characteristics identified by the men and women as important to the success of an intercollegiate athletic administrator were predominately related to psychosocial functions - acceptance and confirmation and role modeling. For the men, role modeling was represented by being trustworthy and respected while acceptance and confirmation were illustrated by being supportive and a good listener. For the women, acceptance and confirmation, as well as role modelling, were represented by being supportive. The psychosocial functions of acceptance and confirmation and role modeling are highly related to the protégé's satisfaction with the mentor. A deeper more intense relationship may evolve and enhance the quality of the mentoring relationship (Kram, 1985).

In addition, the women mentioned being knowledgeable which is supported by the career function of coaching. The mentoring behavior of coaching often leads to the enhancement of task-related aspects of work that facilitate objective career success (Allen, Eby, Poteet, Lentz, \& Lima, 2004). If the coaching facilitation is successful, the protégé may enhance abilities in performing work-related roles (Weaver \& Chelladurai, 2002).

The results of the mentoring characteristics for the women partially support social role theory (Bem, 1974). The women in the study discussed more psychosocial characteristics related to acceptance and confirmation, caring, and nurturing. They also reported the knowledgeable characteristic related to career functions of coaching which is typically seen in men according to social role theory. However, the men's responses were opposite and did not support social role theory. In this study, the men did not discuss career-related characteristics, but rather their responses more strongly reflected the psychosocial characteristics of acceptance and confirmation and role modeling.

\section{Research Question \#2 - What career functions of the mentor were most fre- quently identified as important to the success of male and female intercollegiate athletic administrators?}

The men most frequently identified the career functions of (a) coaching and (b) challenging assignments as important. The male participants explained how they acquired knowledge and expertise as they were "coached" toward pursuing a position in intercollegiate athletic administration. For example, one man said, "My mentor has driven me mentally as well as ethically. They have taught me to be patient and to delegate responsibility. They have taught me to be professional and prepared."

The men were also provided opportunities to learn and grow by being placed in challenging situations by mentors to support their growth. For example, one man's 
mentor, "was someone who was willing to allow me to have ownership of projects and let me really learn while working. . . he helped me along the career path, given me great experiences and included me in major decisions." Another man stated, "I pick my mentors based on their ability to motivate me and challenge me in all areas of my life, not just athletics."

The women most frequently identified career functions which included (a) exposure and visibility and (b) coaching. A woman shared, "it is essential to have people who you can learn from in this business and who can connect you with others." Another woman stated, "I have both male and female mentors invested in assisting me in setting up a network for the future of my career in intercollegiate athletic administration."

The women also acquired knowledge, skills, and productive feedback as they were "coached" by their mentor. For example, a woman stated, "he [mentor] has had a long successful career in athletics and shares his lessons with me and gives corrective feedback." Another woman spoke about her mentor by saying, "[she is a] role model, outstanding and successful coach, with commitment to student-athlete, program and love for institution. Ability to provide constructive and honest feedback."

Comparison of Career Functions. The men identified mentors providing challenging assignments as the most important career function in becoming a successful intercollegiate athletic administrator. By providing challenging assignments, the mentor prepares the protégé for greater responsibility. During this time, the protégé is allowed to develop the technical and managerial skills necessary for a career in intercollegiate athletic administration. The women identified exposure and visibility as their most important career functions in becoming a successful intercollegiate athletic administrator. Exposure and visibility assists with developing relationships in order to be more recognizable to people within the organization. Exposure and visibility also facilitates contact with key leaders who may be useful in securing a future intercollegiate athletic administrative position.

Exposure and visibility may not be as important to the men as they could develop a network and been introduced to key players within this male dominated profession. In other words, the presence of the "old boys network" may come into play here (Wright \& Wright, 1987). Research has shown that women often lack the ability to develop informal networks and therefore may not be as visible to upper level decision makers. Having the opportunity to display talent and competence to senior management and to acquire important information through informal networks is likely to enhance career success (Kram, 1985). The men may already have had the opportunity to establish a network and can begin "getting ahead" by being provided "challenging assignments" while the women are still trying to get to "know" the key leaders in order to be successful.

Both the men and the women identified coaching as important to success in becoming an intercollegiate athletic administrator. Coaching includes transmitting knowledge, offering feedback, providing relevant information, and providing strategies to succeed (Kram, 1985). This type of transmission can be best described through the lens of a constructivist theorist (Kerka, 1998) where learning is most effective 
when knowledge and skills are used to construct meaning for both the protégé and the mentor. The mentor gradually provides less assistance as the protégé internalizes and constructs his/her own knowledge and understanding of what is necessary to be successful as an intercollegiate athletic administrator.

\section{Research Question 3. What psychosocial functions of the mentor were most fre- quently identified as important to the success of male and female intercollegiate athletic administrators?}

The men most frequently identified psychosocial functions that included (a) counseling, (b) role modeling, and (c) acceptance and confirmation. The first theme identified was counseling. For example, one of the men said, "my mentor is always there to listen and provide advice even when I don't want to hear it. Cares about me much more as a person." Another man stated, "he [mentor] understood the challenges and listens to both sides of an issue before making decisions. He cares about people."

The second theme the men most often mentioned related to psychosocial functions was role modeling. One of the participants said, "I actually have both male and female mentors and they are great role models that are honest. They share all the positives, negatives, etc. that help me about with my career and life." Another man added, "my mentor is my role model for life, not just work."

The third theme the men most commonly mentioned was acceptance and confirmation. One of the men spoke about his mentor by saying, “...listens well, offers advice when asked...he understood challenges and listens to both sides of an issue before making decision. He cares about people." Another man focused on the confidence aspect of acceptance and confirmation and explained,

I learned so many things from my mentor. He taught me how to be a leader and what qualities a leader has and how to carry myself that lends confidence. Not to get too high or too low and never let your subordinates see you lose your cool. He taught to be patient and don't be in a hurry and to do things right. Sweat the little details and use your time wisely.

The women most frequently identified psychosocial functions that included (a) counseling, (b) role modeling, and (c) acceptance and confirmation. These themes were identical to the men.

For example, the women described how their mentors assisted in solving personal conflicts which may have distracted them from performing their job effectively. A woman conveyed,

My mentor helps me to analyze situations that I may have issues with and how to overcome them...he is incredibility supportive and encouraging. He is always there to bounce off ideas. He never tries to "solve" my issues and he constantly makes me question what and why! 
Another woman stated,

My mentor has been there to bounce things off of. Good or bad, she guides me but overall allows me to come to the decision. . . she is very supportive and open to conversation. She is not judgmental. She is a resource for many things and has an outside perspective to many athletic related tasks.

The second theme the women most frequently mentioned was role modeling. An intercollegiate athletic administrator spoke about how her mentor acts as a role model,

My female Athletic Director is my greatest mentor, serving as a professional role model, wise sage to my questions, and compassion and understanding with my short comings and learning curve. My external mentors are intra-conference colleagues, who are always happy to answer my questions and share their best practices.

Another woman mentioned her mentor was a "role model, outstanding and successful coach, committed to student-athletes, program and love for institution." Finally, another individual stated,

I use my athletic director as a mentor. I watch how she handles situations and interacts with student athletes, coaches, faculty, and administrators. She is very organized and is always ahead of deadlines. I try to emulate this behavior whenever possible. I try to keep very open lines of communication with her, so I can seek assistance and guidance when needed. She is very good at interacting with people and finding solutions, so I try to learn from her experiences and interactions whenever possible. This has helped me to become more polished and a better administrator. The third theme the women most frequently mentioned was acceptance and confirmation.

For example, one female participant talked about her mentor saying,

Someone that I played for/coached with, that provides support, advice and friendship. Is a role model for women working in the athletic field, always been true to herself, looking to help other females in many roles, not just athletics?

Another woman spoke about her mentors,

The male is a colleague who has provided support to me while achieving promotions from Assistant to A.D., Assistant A.D., Associate A.D. and finally Senior Associate A.D. The female has been a positive influence on my career since the beginning of my employment and is always available for questions, concerns or just reinforcement of the impact I continue to make on my institution. 
Comparison of Psychosocial Functions. Both the men and women identified the same psychosocial functions as important in becoming a successful intercollegiate athletic administrator. The first theme identified was counseling where the mentor was someone who would listen and serve as a sounding board to assist in solving potential internal conflicts (Kram, 1985). Supporting research has established that the more psychosocial support (listening, sharing, caring, emotional support) a protégé receives, the more confident that individual would be in his or her abilities (Kram, 1985).

The second psychosocial theme most frequently identified by the men and women was role modeling. Role modeling provides the protégé with the opportunity to see the mentor in action, efficiently performing organizational tasks while effectively interacting with superiors, peers, and subordinates (Kram, 1985). According to social learning theorists, the protégé acquires important managerial skills by observing an effective senior manager (Bandura, 1977). This psychosocial function is likely to affect the career outcomes through a positive effect on the learning process.

The third theme most often identified was acceptance and confirmation. Acceptance and confirmation focused on the support the mentor provided by expressing confidence, creating mutual trust, confirming individual abilities, and lending encouragement and support.

\section{Implications}

The results of the study provided implications for intercollegiate athletic administrators who wish to advance in their careers and are considering how working with a mentor could assist them. First, a potential protégé needs to reflect on whether a mentor has the characteristics and career and/or psychosocial skills necessary to help $\mathrm{him} / \mathrm{her}$ achieve the goal of advancing in intercollegiate athletic administration. For example, the Athletic Director in the protégé's athletic department may be a wellknown industry professional but may not be the best match as mentor. If this is the case, the protégé needs to look elsewhere to find someone who can help with the necessary career and psychosocial functions to assist in his/her career advancement. That person may or may not even work in intercollegiate athletics as a number of respondents in the study indicated their mentors did not. People outside of the athletics realm can still provide useful career information, and as matter of fact, having someone removed from the daily life in athletics may actually provide the protégé with a different outlook on career advancement. Second, learning about career and psychosocial functions is an important element in any mentoring relationship (Kram, 1985). Third, the study provided information on the career and psychosocial functions useful in becoming an intercollegiate athletic administrator. These career and psychosocial functions may be useful to help protégés excel in the profession. Fourth, career and psychosocial functions were important to the development of the mentoring relationship. Thus, sport organizations may benefit from implementing formal mentoring programs that integrate career and psychosocial functions fostering career development for becoming an intercollegiate athletic administrator. These 
formal mentoring programs may provide insight on helping both the mentor and protégé develop tactics for facilitating a prolonged and useful relationship.

\section{Limitations}

There were a couple of limitations to the study. The researchers already addressed the low return rate and provided justification and support of why the number was low. However, an increase in the number of participants may provide additional insight and representation not provided within this study. In addition, the participants provided limited responses when it came to answer the open-ended questions. The researchers expected the data might have provided more fulfilling insights with respect to characteristics, career and psychosocial functions.

\section{Future Research}

The results provided direction for future research. Men and women from other segments of the sport industry may be examined to see if there are similarities or differences in the role of characteristics and functions. For example, professional sport or recreational sport may be studied. Are the characteristics, career, and psychosocial functions identified by the male and female participants in this study similar to those in other segments of the sport industry? This study also laid out some baseline information on the specific career experiences of men working in intercollegiate athletics. We have seen a good number of researchers examining women's career experiences, but the men's experiences need to be further examined. By doing so, researchers can better understand some of the dynamics of career development not only for the men, but how those experiences compare to the experience of women working in intercollegiate athletic administration. Results of studies such as these could help athletic administrators remove barriers to women's advancement in this segment of the sport industry. The investigations that result from this study should not be limited to the sport industry. Perhaps similar investigations into mentoring and career advancement could take place in industries such as accounting, marketing, or film, where the exploration of mentoring experiences of men and women have not yet been undertaken. So often, Sport Management researchers base our work on theories and studies from other disciplines. Perhaps this work could provide the opportunity for researchers in other industries to look to the Sport Management literature for guidance. While comparisons by race or ethnicity would provide valuable information, the low number of minority group respondents would make any comparison in this study problematic. Future phenomenological qualitative research with minority athletic administrators utilizing in-depth interviews will provide a more robust examination of the impact of mentoring relationships on their careers. A study using a similar methodology where participants from NCAA Division I, II, or III are interviewed could also address whether mentoring relationships vary depending on the division in which one works. Further inquiry should be made to examine the gender of the mentor to determine if 
there is a significant difference on career advancement for women who have samesex and opposite-sex mentoring relationships. Does the gender of the mentor make a difference in the success of a female intercollegiate athletic administrator?

\section{Conclusion}

The intercollegiate athletic administrators in this study provided insights into how effective mentoring relationships are essential to the advancement of men and women working in intercollegiate athletic administration. The study identified valuable characteristics, career functions, and psychosocial functions that were helpful in developing effective mentoring relationships. Having a mentor may balance the career and psychosocial functions and is beneficial to the growth of athletic administrators at various career levels.

\section{References}

Acosta, R. V., \& Carpenter, L. J. (2014). Women in intercollegiate sport. A longitudinal national study, Thirty-seven-year updates, 1977-2014. Available for downloading at www.acostacarpenter.org.

Allen, T. D., \& Eby, L. T. (2004). Factors related to mentor reports of mentoring functions provided: Gender and relational characteristics. Sex Roles, 50(1/2), 129-139.

Allen, T. D., Eby, L. T., Poteet, M. L., Lentz, E., \& Lima, L. (2004). Career benefits associated with mentoring for protégés: A meta-analysis. Journal of Applied Psychology, 89(1), 127-136.

Allen, T. D, Poteet, M. L., \& Burroughs, S. M. (1997). Career benefits associated with mentoring for proteges: A meta-analysis. Journal of Applied Psychology, 89, 127-136.

Allen, T. D., Russell, J. E. A., \& Maetzke, S. (1997). Formal peer mentoring: Factors related to protégés satisfaction and willingness to mentor others. Group and Organization Management, 22, 488-507.

Avery, D. R., Tonidandel, S., \& Phillips, M. G. (2008). Similarity on sports sidelines: How mentor-protégé sex similarity affects mentoring. Sex Roles, 58, 72-80.

Bandura, A. (1977). Self-efficacy: Toward a unifying theory of behavioral change. Psychological Review, 84(2), 191-215.

Bem, S. L. (1974). The measurement of psychological androgyny. Journal of Consulting and Clinical Psychology, 42, 155-162.

Bickel, J. (2014). How men can excel as mentors of women. Academic Medicine, 89(8), 1100- 1102.

Bloom, G. A., Durand-Bush, N., Schinke, R. J., \& Salmella, J. H. (1998). The importance of mentoring in the development of coaches and athletes. International Journal of Sport Psychology, 29, 267-281. 
Bower, G. G. (2011). The examination of the mentoring relationship between the head coach and assistant coach of women's basketball teams. Advancing Women in Leadership Journal, 31(1), 1-7.

Bower, G. G. (2006). Mentoring faculty toward connecting and collaborating within Physical Education Departments. The ICHPERD-SD Journal of Research (The International Council for Health, Physical Education, Recreation and Dance), XLII (2), 18-24.

Bower, G. G., \& Hums, M. A. (2014). Examining the mentoring relationship of women working within intercollegiate athletic administration. Mentoring and Tutoring Journal, 22(1), 4- 19.

Bower, G. G., \& Hums, M.A. (2013). Career paths of women working in leadership positions with intercollegiate athletics. Advancing Women in Leadership Journal, 33(1), 1-14.

Bower, G. G., \& Hums, M. A. (2003). Women working in the administration of campus recreation. NIRSA Recreational Sports Journal, 27, 35.

Bower, G. G., Hums, M. A., \& Keedy, J. L. (2006). Factors influencing the willingness to mentor females in leadership positions within campus recreation: A historical perspective. Advancing Women in Leadership, 20, 1-13.

Burke, R. J., McKeen, C. A., \& McKenna, C. (1993). Correlates of mentoring in organization: The mentor's perspective. Psychological Reports, 72, 883-896.

Chester, M. N., \& Mondello, M. (2012). Mentorship among female sport management doctoral students. Sport Management Education Journal, 6(1), 53-68.

Dougherty, T.W., Dreher, G.F., Arunachalam, V., \& Wilbanks, J.E. (2013). Mentor status, occupational context, and protégé career outcomes: Differential returns for males and females. Journal of Vocational Behavior, 83, 514-527.

Erlandson, D. A., Harris, E. L., Skipper, B. L., \& Allen, S. D. (1993). Doing naturalistic inquiry: A guide to methods. Newbury Park, CA: Sage.

Forret, M. L., \& Dougherty, T. W. (2004). Networking behaviors and career outcomes: Differences for men and women? Journal of Organizational Behavior, 25, 419-437.

Hackett, G., \& Betz, N. E. (1981). A self-efficacy approach to the career development of women. Journal of Vocational Behavior, 18(3), 326-339

Hancock, M. G., Grappendorf, H., Wells, J., \& Burton, L. (2017). Career breakthroughs of women in intercollegiate athletic administration: What is the role of mentoring? Journal of Intercollegiate Sport, 10, 184-206.

Hums, M. A., \& Moorman, A. (1999). Kentucky women working in sport management. KAHPERD Journal, 35, 29-33.

Hums, M. A., \& Sutton, W. A. (1999). Women working in the management of professional baseball: Getting to first base? Journal of Career Development, 26, 147-158.

Inglis, S., Danylchuk, K. E., \& Pastore, D. L. (2000). Multiple realities of women's experiences in coaching and athletic management: Listening to the voices. Women in Sport and Physical Activity Journal, 9, 1-26. 
Itoh, M. (2014). Role models, leadership and self-efficacy and careers of women working in the management of professional baseball. Unpublished doctoral dissertation, University of Louisville.

Kerka, S. (1998). New perspectives on mentoring. ERICDigest [On-line]. Retrieved from https://files.eric.ed.gov/fulltext/ED418249.pdf

Kram, K. E. (1985). Mentoring at work. Glenview, IL: Scot, Foresman.

Lapchick, R. (2018). The 2017 racial and gender report card. Institute for Diversity and Ethics in Sport. Retrieved from http://nebula.wsimg.com/5665825afd75728dc0c45b52ae6c412d? AccessKeyId=DAC3A56D8FB782449D2A\&disposition $=0$ \&alloworigin $=1$.

Lincoln, Y. S., \& Guba, E. G. (1985). Naturalistic inquiry. Beverly Hills, CA: Sage. Lough, N. L. (2001). Mentoring connections between coaches and female athletes. Journal of Physical Education, Recreation, \& Dance, 72(5), 30-33.

Lumpkin, A., Achen, R. M., \& Hyland, S. (2015). Education, experiences, and advancement of athletic directors in NCAA member institutions. Journal of Contemporary Athletics, 9(4), 249-265.

Machida-Kosuga, Schaubroeck, J., \& Feltz, D. (2016). Leader self-efficacy of women intercollegiate athletic administrators: A look at barriers and developmental antecedents Journal of Intercollegiate Athletics, 9(2), 157-178.

Neuman, W. L. (2010). Social research methods: Qualitative and quantitative approaches ( $6^{\text {th }}$ edition). Boston, MA: Allyn and Bacon.

Olian, J. D., Carroll, S. J., \& Giannantionio, C. M. (1993). Mentor reactions to protégés: An experiment with managers. Journal of Vocational Behavior, 43(3), 266-278.

Olson, K. (2006). Survey participation, nonresponse bias, measurement error bias, and total bias. Public Opinion Quarterly, 70(5), 737-758.

Ragins, B. R. (1997). Diversified mentoring relationships in organizations. A power perspective. The Academy of Management Review, 22(2), 482-521.

Ragins, B. R. (2002). Understanding diversified mentoring relationships: Definitions, challenges, and strategies. In D. Clutterbuck \& B. R. Ragins (Eds.), Mentoring and diversity: An international perspective (pp. 23-53). Boston, MA: Butterworth Heinemann.

Ragins, B. R., \& Cotton, J. L. (1999). Mentor functions and outcomes: A comparison of men and women in formal and informal mentoring relationships. Journal of Applied Psychology, 84(4), 529-550.

Ragins, B. R., \& Sundstrom. E. (1989). Gender and power in organizations: A longitudinal perspective. Psychological Bulletin, 105, 51-88.

Ransdell, L.B., Nguyen, N., Hums, M.A., Clark, M., \& Williams, S.B. (2017): Voices from the field: Perspectives of U.S. Kinesiology Chairs on opportunities, challenges, and the role of mentoring in the Chair position, Quest, DOI: $10.1080 / 00336297.2017 .1371047$

Rossman, G. B., \& Rallis, S. F. (2011). Learning in the field: An introduction to qualitative research, $3^{\text {rd }}$ edition. Thousand Oaks, CA: Sage Publications. 
Schneider, R. C., Stier, W. F., Henry, T. J., \& Wilding, G. E. (2010). Title IX compliance in NCAA athletic departments: Perceptions of senior woman administrators. Journal of Human Kinetics, 23, 91-98. Retrieved from: http://www.johk. awf.katowice.pl/

Smith, A. B., Taylor, E. A., \& Hardin, R. (2017). Women and mentoring in collegiate athletics. Mentoring \& Tutoring: Partnership in Learning, 24(5), 346-364.

Taylor, E. A., \& Wells, J. E. (2017). Institutionalized barriers and supports of female athletic directors: A multilevel perspective. Journal of Intercollegiate Sport, 10(2), 157-183.

Walker, N. A., \& Bopp, T. (2011). The underrepresentation of women in the male-dominated sport workplace: Perspectives of female coaches. Journal of Workplace Rights, 15(1), 47- 64.

Weaver, M. A., \& Chelladurai, P. (2002). Mentoring in intercollegiate athletic administration. Journal of Sport Management, 16, 96-116.

Weaver, M. A., \& Chelladurai, P. (1999). A mentoring model for management in sport and physical education. Quest, 51, 24-38.

Whisnant, W. A., Pedersen, P. M., \& Obenour, B. L. (2002). Success and gender: Determining the rate of advancement for intercollegiate athletic directors. Sex Roles, 47, 485-491.

Wright, C. A., \& Wright, S. D. (1987). The role of mentors in career development of young 4 professionals. Family Relations, 36(2), 204-208. 